\title{
NOTES
}

\section{STANDING WHILE BLACK: DISTINGUISHING LYONS IN RACIAL PROFILING CASES}

\section{Brandon Garrett}

Plaintiffs challenging racial profiling must contend with the Supreme Court's decision in City of Los Angeles v. Lyons, which restricted standing for injunctive relief against government officials. This Note articulates a framework for assessing standing for injunctive relief based on case law following Lyons: Plaintiff must demonstrate a sufficiently "credible threat" of future harm where government conduct was authorized by a policy, practice, or custom and where plaintiff was law-abiding.

Lyons analysis focuses exclusively on an individual's likelihood of future harm because the Court was reluctant to let the grievance of one individual support city-wide injunctive relief. Where racial profiling cases raise equal protection claims alleging that groups of individuals are targeted by police, the concerns supporting the Lyons requirement become less relevant. Although the Court has never explicitly distinguished Lyons, in the Court's equal protection decisions, standing is presumed where a group is harmed. Following these decisions, Lyons should be distinguished in racial profiling cases.

\section{INTRODUCTION}

We have learned that there are cars we are not supposed to drive, streets we are not supposed to walk. We may still be stopped and asked "Where are you going, boy?" whether we're in a Mercedes or a Volkswagen. ${ }^{1}$

An African-American male driving his car or walking down the street faces a greater likelihood of pretextual police stops than his white counterpart in many areas of the country. ${ }^{2}$ Police defend the use of criminal A25.

1. Don Jackson, Police Embody Racism to My People, N.Y. Times, Jan. 23, 1989, at

2. See Peter Verniero, Office of the Att'y Gen. of the State of New Jersey, Interim Report of the State Police Review Team Regarding Allegations of Racial Profiling 27 (1999) (" $[\mathrm{T}]$ he overwhelming majority of searches $(77.2 \%)$ involved black or Hispanic persons."); Elliot Spitzer, Office of the Att'y Gen. of the State of New York, The New York City Police Department's "Stop \& Frisk" Practices 94-95 (1999) (finding that blacks comprise $25.6 \%$ of New York City's population, but $50.6 \%$ of all persons "stopped" were black; whites comprise $43.4 \%$ of the City's population but $12.9 \%$ of all persons "stopped"); Sean Hecker, Race and Pretextual Traffic Stops: An Expanded Role for Civilian Review Boards, 28 Colum. Hum. Rts. L. Rev. 551, 551-55 (1997) ("From the New Jersey Turnpike to the I-95 corridor between Delaware and Florida, empirical studies strongly suggest that police single out minority, particularly African-American, motorists for traffic stops."); Kris Antonelli, State Police Deny Searches are Race-Based, Baltimore Sun, Nov. 16, 1996, at 18B (noting that a 1996 ACLU study found that though $17 \%$ of motorists on Interstate 95 were 
profiles that target minorities, a practice commonly known as racial profiling, as a means of reaching likely criminal behavior. ${ }^{3}$ For critics, racial profiling brands minorities as criminals, though their only fault is "driving while black." 4 As opposition to racial profiling mounts, private plaintiffs aided by public interest groups are challenging these police practices in federal court, leading a nationwide groundswell of federal litigation challenging racial profiling. ${ }^{5}$ Obtaining equitable relief is a critical goal of litigation where police departments are willing to ignore large damage

black, blacks accounted for $73 \%$ of motorists that police stopped); Poll Finds Most in U.S. Believe Police Practice "Racial Profiling," Chi. Trib., Dec. 11, 1999, at 15 (describing a recent Gallup poll in which a majority of Americans said they believed that racial profiling is widespread and three-fourths of black men said they have been stopped by police because of their race).

3. See David Cole, No Equal Justice 34-41 (1999) [hereinafter Cole, No Equal Justice] (describing the explicit use of race in drug courier profiles by police departments in Maryland, Colorado, Louisiana, and New Jersey); Michael A. Fletcher, Driven to Extremes: Black Men Take Steps to Avoid Police Stops, Wash. Post, Mar. 29, 1996, at Al (stating that the Maryland State Police characterize the disproportionate stopping of minorities as "an unfortunate byproduct of sound police policies").

4. See Washington v. Lambert, 98 F.3d 1181, 1188 (9th Cir. 1996) ("There's a moving violation that many African-Americans know as D.W.B.: Driving While Black." (quoting Henry L. Gates, Jr., Thirteen Ways of Looking at a Black Man, New Yorker, Oct. 23, 1995, at 59)). Recognizing that the targets of racial profiling are not limited to AfricanAmericans, I use the phrase "driving while black" rather than a more inclusive phrase such as "driving while black or brown" only because the former was originally coined to describe the practice of racial profiling.

5. Almost every major city and state police department has faced lawsuits or investigations of racial profiling in the past few years. Recent litigation includes: Rodriguez v. California Highway Patrol, 89 F. Supp. 2d 1131, 1134 (N.D. Cal. 2000) (alleging racial profiling by the California state police); National Congress for Puerto Rican Rights v. City of New York, 75 F. Supp. 2d 154, 161 (S.D.N.Y. 1999) (involving violations alleged against tens of thousands of predominantly minority New Yorkers); Chavez v. Illinois State Police, No. 94-C5307, 1999 WL 592187, at *20, *22 (N.D. Ill. Aug. 2, 1999) (dismissing case involving thousands of traffic stops throughout Illinois); see also Robert Jackson, Minorities Win Suit Over Unfair I-70 Stops, Rocky Mountain News, Nov. 10, 1995, at $4 \mathrm{~A}$ (discussing settlement in lawsuit against the Eagle County Sheriff's Department, which included $\$ 800,000$ in damages, abandoning the "High Country Drug Task Force," and requiring reasonable suspicion for traffic stops). The American Civil Liberties Union (ACLU) is coordinating a national litigation and advocacy campaign centered on racial profiling. American Civil Liberties Union, Arrest the Racism: Racial Profiling in America (visited Oct. 3, 2000) <http://www.aclu.org/profiling/background/ index.html/> (on file with the Columbia Law Review) (describing the ACLU's litigation campaign, legal hotline, research and public education efforts).

While the Justice Department and states are investigating police brutality in places like Los Angeles, New York City and New Jersey where police killings or corruption scandals drew attention to racial profiling, private suits have been critical catalysts in smaller communities. Given the inadequate resources of the Justice Department, private plaintiffs may be the primary source of redress for racial profiling in the future. See Jerome $\mathbf{H}$. Skolnick \& James J. Fyfe, Above the Law 211 (1993) (noting that the Justice Department has only 44 civil rights prosecutors and, from 1982-1989, brought only 22 "significant" police brutality prosecutions). 
awards rather than alter pervasive practices of police brutality or racial profiling. ${ }^{6}$

At the outset of litigation challenging racial profiling, plaintiffs must contend with the Supreme Court's decision in City of Los Angeles v. Lyons, which restricts standing for plaintiffs seeking equitable relief against government officials. ${ }^{7}$ In Lyons, a man was stopped by city police officers for allegedly driving with a faulty taillight and was choked until he became unconscious. The Court held that the plaintiff, who was seeking an injunction against the police department, lacked standing, stating that plaintiffs must show sufficient likelihood of future injury to warrant injunctive relief. The Court did not mention that Lyons was black, nor that twelve of sixteen others killed by such chokeholds were also black. Commentators criticizing Lyons argued that the Court ignored racial aspects of policing ${ }^{8}$ and that the Lyons standard for injunctive relief required plaintiffs to show a "virtual certainty of future injury"-an insurmountable hurdle. ${ }^{9}$

Despite the fear that the standard in Lyons would be difficult to meet, the approach followed by courts since Lyons has afforded plaintiffs standing for injunctive relief against government officials in a wide range of factual circumstances. ${ }^{10}$ Part $I$ of this Note articulates a framework derived from the post-Lyons case law to assess standing for injunctive relief. Under this approach, the question of whether an individual plaintiff seeking injunctive relief faces a "credible threat" of future injury is determined by focusing on two factors: (1) whether government conduct was authorized by a policy, practice, or custom of official misconduct; and (2) whether plaintiff was law-abiding or instead precipitated the encounter by engaging in avoidable behavior. If the challenged official conduct was

6. See Skolnick \& Fyfe, supra note 5, at 202-05 (describing how like other large metropolitan police departments, the Los Angeles Police Department pays millions of dollars every year in damages in police brutality cases, yet, rather than change its practices, ignores the judgments, does not inform officers of the awards, and writes off the losses as "a reasonable price for the presumed deterrent effect of the department's most violent responses to lawbreaking").

7. 461 U.S. 95 (1983).

8. See The Supreme Court, 1982 Term, 97 Harv. L. Rev. 208, 223 (1983) [hereinafter 1982 Term] ("The Lyons Court belittled-by ignoring-the seriousness of the police brutality faced by blacks ....").

9. Linda E. Fisher, Caging Lyons: The Availability of Injunctive Relief in Section 1983 Actions, 18 Loy. U. Chi. L.J. 1085, 1097 (1987). See also Laurence H. Tribe, Constitutional Choices 102 (1985) (criticizing requirement of near certainty of future injury); $1982 \mathrm{Term}$, supra note 8 , at 220 ("[T] he majority's unprecedentedly high case-or-controversy threshold may constitute a major obstacle for civil rights plaintiffs.").

10. See, e.g., Hernandez v. Cremer, 913 F.2d 230, 237 (5th Cir. 1990) (requiring the INS to perform procedures before attempting to exclude those presenting documentary evidence of U.S. citizenship); LaDuke v. Nelson, 762 F.2d 1318, 1331-32 (9th Cir. 1985) (enjoining the INS from conducting warrantless farm searches); National Congress for Puerto Rican Rights, 75 F. Supp. 2d. at 161 ("Courts have not been hesitant to grant standing to sue for injunctive relief where numerous constitutional violations have resulted from a policy of unconstitutional practices by law enforcement officers."). 
authorized and plaintiff was law-abiding, a court will usually conclude that plaintiffs have standing.

Racial profiling introduces a new factor to the Lyons calculus. Racial profiling involves groups of individuals who are targeted by police. Part I of this Note concludes by proposing an alternative approach to standing in racial profiling cases, in which courts would recognize that persons who are targeted based on group characteristics face a greater likelihood of future injury and thus satisfy the Lyons requirement.

Even this alternative approach does not fully recognize the central concern in racial profiling cases: Racial profiling involves discriminatory action that impacts fundamental equal protection values. The Lyons case law is not well suited to address problems in racial profiling cases, since the Lyons decision did not discuss race, nor did the plaintiff properly allege an equal protection claim. The Lyons line of cases focuses on individual rather than group-based harm. Indeed, the Lyons decision added extra requirements for standing in part because the Court was reluctant to let the "generalized grievance" of one individual harmed in one encounter permit city-wide injunctive relief. But in the context of equal protection claims alleging that persons are targeted by virtue of membership in a suspect group, the prudential concerns supporting the Lyons requirements become irrelevant.

Part II of this Note contends that Lyons has needlessly distracted courts from focusing solely on group harm in racial profiling cases alleging equal protection violations. Although the Court has never explicitly distinguished Lyons, the Court's equal protection decisions, most notably in voting rights cases, support the proposition that group harm in itself suffices to satisfy standing requirements. Racial profiling cases raising equal protection claims may satisfy the Lyons requirements, but in some cases distinguishing Lyons based on this theory of group-based harm may save a suit from dismissal. As plaintiffs increasingly allege equal protection violations in racial profiling cases, the need for distinguishing Lyons becomes more critical. ${ }^{11}$

\section{The Lyons Framework}

\section{A. The Lyons Decision}

Adolph Lyons was allegedly pulled over by the Los Angeles Police Department (LAPD) because he was driving with a faulty taillight. ${ }^{12}$ The officers drew their guns and ordered Lyons to step out and stand next to his car, and Lyons followed their instructions, exiting, raising his hands and standing next to his car. ${ }^{13}$ One officer grabbed Lyons by the throat without any provocation, handcuffed him, and then choked him until he

11. See infra note 60 and accompanying text.

12. See Lyons, 461 U.S. at 114 (Marshall, J., dissenting).

13. See id. 
was unconscious. ${ }^{14}$ Lyons regained consciousness on the ground, spitting blood and dirt, having urinated and defecated. ${ }^{15}$ The officers left him lying there after issuing a traffic ticket for the taillight. ${ }^{16}$ Lyons was fortunate to survive; sixteen others were killed by LAPD chokeholds, twelve of whom were black. ${ }^{17}$ Lyons brought a federal suit seeking not only compensatory relief, but also injunctive and declaratory relief to protect himself and others similarly situated from suffering irreparable physical harm from future chokeholds.

The Lyons Court, applying a new test, concluded that Lyons lacked standing to seek injunctive relief. Typically, to satisfy the standing requirements of an Article III "case or controversy," a party seeking federal jurisdiction must show: (1) an injury in fact that is both (a) concrete and particularized, and (b) actual or imminent; (2) that the injury is fairly traceable to the acts of the defendant; and (3) a likelihood that the injury would be redressed by a decision favorable to the plaintiff. ${ }^{18}$ In a departure from previous decisions, the Court concluded that plaintiffs must satisfy these standing requirements for each type of relief sought and, further, that plaintiffs seeking injunctive or declaratory relief must show an additional likelihood of future injury. ${ }^{19}$ The Lyons Court justified this departure by briefly expressing concern about "restraint in the issuance of injunctions against state officers engaged in the administration of the States' criminal laws . . . ."20 The dissent countered that predict-

14. See id. at 115 .

15. See id.

16. See id.

17. See id. at 115-16.

18. See Lujan v. Defenders of Wildlife, 504 U.S. 555, 560-62 (1992).

19. This Note does not address a separate criticism of the Lyons decision-that Lyons is not a case about standing doctrine, but rather a case involving related requirements of ripeness and mootness. However described, the Lyons doctrine is consistently applied in cases requesting injunctive relief. For a discussion of the similarities between the Lyons standing requirements and ripeness and mootness doctrines, see Richard $\mathrm{H}$. Fallon, Jr. et. al, Hart and Wechsler's The Federal Courts and the Federal System 268 (4th ed. 1996) (suggesting Lyons is a ripeness case, since the Court held that no credible threat had materialized); Richard H. Fallon, Jr., Of Justiciability, Remedies, and Public Law Litigation: Notes on the Jurisprudence of Lyons, 59 N.Y.U. L. Rev. 1, 24 (1984) [hereinafter Fallon, Of Justiciability] (arguing that mootness is a plausible rubric for Lyons, since the issue is whether injury was completed).

20. Lyons, 461 U.S. at 112 . Although courts have indicated that they may be influenced by concerns of equity and comity, this Note does not focus on such concerns, as no court has found equity and comity concerns dispositive. See Hodgers-Durgin v. De La Vina, 199 F.3d 1037, 1042-44, 1045-48 (9th Cir. 1999) (denying injunctive relief based in part on equitable restraint, though a concurrence emphasizes traditional Lyons analysis and states that discussion of federalism is dicta); see also Curtis v. City of New Haven, 726 F.2d 65, 69 (2d Cir. 1984) (" $[\mathrm{T}]$ he injunction at issue here would inject the federal courts into the internal policies of the New Haven police department . . . ."); Gonzales v. City of Peoria, 722 F.2d 468, 481 (9th Cir. 1983) (denying standing wbere there was no practice of misconduct, but briefly stating a federalism conceru). Denying equitable relief for comity reasons in a Section 1983 suit may be improper because Section 1983 was arguably intended to permit equitable relief against defendants acting under color of state law. See 
ing the scope of the remedy at the standing stage was improper and premature. ${ }^{21}$

The Court reasoned that since the purpose of prospective relief was to deter future injury, plaintiffs must make a showing of a credible threat of future harm. The Lyons Court concluded that future harm would be likely if: (1) police followed a policy, practice, or custom; and (2) plaintiff was law-abiding. Lyons failed on both grounds. First, Lyons failed to allege a policy or practice extending to his particular situation, where the victim did not resist or provoke the police, much less threaten death or grievous bodily harm. ${ }^{22}$ It may be unrealistic to expect solitary victims of abuse to canvas a city to find others hurt in a similar way-especially where other victims are dead-but the Court held that if injury is due to unauthorized force, prospective relief is improper. Second, Lyons violated the law, which the Court assumed plaintiffs would not do in the future.

\section{B. Credible Threat of Future Harm}

The Lyons Court articulated a new standing requirement: Plaintiffs seeking equitable relief must show an additional likelihood of future harm. This likelihood of future harm requirement is satisfied when plaintiffs show a "credible threat" of future harm. A plaintiff must "credibly allege that he face[s] a realistic threat from the future application of the City's policy." ${ }^{23}$ One month following Lyons, in Kolender $v$. Lawson, the Court reiterated the "credible threat" standard for standing. ${ }^{24}$ Since

Monroe v. Pape, 365 U.S. 167, 173 (1961). Lyons was also a departure from O'Shea $v$. Littleton and Rizzo v. Goode, both cited by the majority in Lyons, where restraint was far more justified because structural relief was requested. See Rizzo v. Goode, 423 U.S. 362, 379 (1976) (involving an injunction which "significantly revis[ed] the internal procedures" of the police department and where the court would engage in supervision of police); $O$ 'Shea v. Littleton, 414 U.S. 488, 504 (1974) (involving an "abrasive and unmanageable intercession" into state criminal proceedings).

21. See Lyons, 461 U.S. at 130 (Marshall, J., dissenting) ("The federal practice has been to reserve consideration of the appropriate relief until after a determination of the merits . . . .). For criticism of this aspect of Lyons, see Laura E. Little, It's About Time: Unravelling Standing and Equitable Ripeness, 41 Buff. L. Rev. 983 (1993) (argning that equitable principles are flexible and provide judicial discretion, unlike standing principles, which provide clear threshold rules telling plaintiffs if they can sue).

22. See Lyons, 461 U.S. at 106; see also Maryland State Conference of NAACP Branches v. Maryland Dept. of State Police, 72 F. Supp. 2d 560, 564-65 (D. Md. 1999) ("The Lyons complaint, on the other hand, did not assert that there was a pattern and practice of applying chokeholds without provocation or, if it did state such a claim, the Court found it was not supported by the record.").

23. Lyons, 461 U.S. at 107 n.7.

24. 461 U.S. 352,355 n.3 (1983) (finding standing to challenge a California antiloitering statute because plaintiff was arrested 15 times in two years, so he had shown a "credible threat" of future injury). 
Lyons and Kolender, most courts have adopted this credible threat standard for assessing future likelihood of injury. ${ }^{25}$

Determination of credible threat is a flexible, individualized inquiry that is left to the discretion of the court. Specifically, a court determines credible threat by analyzing examples of prior official conduct. ${ }^{26}$ Courts follow a highly fact-specific inquiry and proceed by assessing whether the police follow a practice of misconduct and whether police will continue to follow this practice. ${ }^{27}$

The credible threat standard also sensibly mirrors related justiciability requirements of ripeness and mootness. Although commentators have debated over whether Lyons is properly considered a ripeness or mootness case, the debate has little practical relevance today because the credible threat standard applied in Lyons cases is basically the same as the standards applied in the mootness and ripeness contexts. ${ }^{28}$ The standard

25. See Friends of the Earth, Inc. v. Laidlaw Envtl. Servs. (TOC), Inc., 120 S. Ct. 693, 706 (2000) (stating that Lyons did not have standing because "he could not credibly allege that he faced a realistic threat from the policy"); Allen v. Wright, 468 U.S. 737, 760 n. 25 (1984) (describing Lyons as requiring a "realistic threat of being subject to the challenged practice"); Harris v. Champion, 51 F.3d 901, 907 (10th Cir. 1995) (denying standing but emphasizing that Lyons requires a realistic threat); Church v. City of Huntsville, 30 F.3d 1332, 1337-39 (11th Cir. 1994) (citing Lyons's "realistic threat" language, comparing likelihood as a matter of degree); American Postal Workers Union v. Frank, 968 F.2d 1373, 1375-76 (1st Cir. 1992) (repeating that Lyons requires that plaintiff be "realistically threatened"); Thomas v. County of Los Angeles, 978 F.2d 504, 507 (9th Cir. 1992) ("Lyons needed to "credibly allege that he faced a realistic threat from the future application of the City's policy.' " (quoting Lyons, 461 U.S. at 107 n.7)); Hill v. City of Houston, 764 F.2d 1156, 1161 (5th Cir. 1985) (finding that four arrests and intent to continue engaging in conduct violating ordinance satisfies Lyons requirement of "credible threat" of future prosecution (quoting Kolender, 461 U.S. at 355 n.3)); LaDuke v. Nelson, 762 F.2d 1318, 1323 (9th Cir. 1985) (emphasizing that the Lyons standard is that plaintiff show a "credible threat" of future harm (quoting Kolender, 461 U.S. at 355 n.3)); Curtis, 726 F.2d at 67 (2d Cir. 1984) ("the critical standing inquiry is whether a plaintiff is "realistically threatened by a repetition of his experience. ..' or whether the claim is 'speculative.' (quoting Lyons, 461 U.S. at 109)); Franklin v. City of Chicago, 102 F.R.D. 944, 947 (N.D. Ill. 1984) (finding standing where plaintiff showed a "realistic threat" of future harm).

26. The Supreme Court initially denied certiorari for Lyons and only accepted the case after a preliminary injunction hearing had been held and a more substantial record of the facts surrounding the allegations had been developed. See City of Los Angeles v. Lyons, 449 U.S. 934 (1980) (denying certiorari); Lyons, 461 U.S. at 99-102. Justice Marshall, in his dissent, emphasized that standing should only be considered after discovery, arguing, "[I]t will rarely be easy to decide with any certainty at the outset of a lawsuit that no equitable relief would be appropriate under any conceivable set of facts. .." Lyoms, 461 U.S. at 131 . Courts following Lyons have denied standing only after a trial or at the preliminary injunction stage.

27. See, e.g., Deshawn v. Safir, 156 F.3d 340, 345 (2d Cir. 1998) (discussing police documents and noting that standing can be based on an examination of "evidence of recurrence"); Alliance of Am. Insurers v. Cuomo, 854 F.2d 591, 596 (2d Cir. 1988) ("The difference between a threatened injury and a conjectural one is a matter of degree, and since no precise test exists, each case must be considered on an individual basis.").

28. See supra note 19. Richard Fallon found Lyons's standing requirements overly restrictive when compared to the mootness requirement of a reasonable likelihood of 
is also similar to that required for the redressability prong of standing, which is not difficult to satisfy when alleging concrete injury. ${ }^{29}$

\section{Factors Supporting Credible Threat}

The credible threat standard allows courts to make an individualized inquiry into the likelihood of future harm. The latitude accorded courts led Professor Erwin Chemerinsky to contend that the Lyons requirement provides insufficient guidance, presenting courts with "a line-drawing problem of how much certainty must exist that a person will be harmed in the future in order for the individual to have standing to seek equitable relief." 30 Since Lyons, though, courts have settled upon a coherent way of assessing certainty by examining two factors. The court's analysis in Thomas $v$. County of Los Angeles demonstrates this approach:

[T] he record before this court indicates that numerous instances of police misconduct have occurred in a small six by seven block area, some minority residents of the area have been mistreated by deputies more than once, and many victims purportedly did nothing to warrant detention or apprehension prior to the mistreatment. Moreover, plaintiffs have alleged that the misconduct is purposefully aimed at minorities and that such misconduct was condoned and tacitly authorized by department policymakers. We conclude that the plaintiffs have alleged a "real and immediate threat of injury" . . . 31

First, the Thomas court found evidence of a policy or pattern of police abuse based on "numerous instances of police misconduct." Next, the court emphasized that plaintiffs did not precipitate the mistreatment. The foregoing two-part analysis exemplifies the post-Lyons approach to standing for equitable relief. ${ }^{32}$ The Thomas court also emphasized that minorities are targeted by police, suggesting a third concern, race dis-

future injury. See Fallon, Of Justiciability, supra note 19, at 26. The realistic or credible threat standard as it has been applied, however, is very similar to a requirement of reasonable likelihood. The standards may be identical. A recent Supreme Court case found it necessary to distinguish Lyons in a mootness case. See Honig v. Doe, 484 U.S. 305, 320 (1988). Mootness differs from standing where injuries that are "capable of repetition yet evading review" satisfy mootness requirements. But see Gallman v. Pierce, 639 F. Supp. 472, 479-80,(N.D. Cal. 1986) (finding justiciability on two alternate grounds: (1) Lyons standing was satisfied, and (2) the case satisfied the "capable of repetition, yet evading review" exception to mootness). Lyons even leaves open the possibility of an exception under mootness doctrine. See Lyons, 461 U.S. at 110.

29. See Lujan v. Defenders of Wildlife, 504 U.S. 555, 564 (1992) (invoking Lyons and requiring some specification of when or how future injury might occur); see also Duke Power Co. v. Carolina Envtl. Study Group, Inc., 438 U.S. 59, 75 n.20 (1978) (requiring only that plaintiff show "substantial likelihood" that harm is redressable); Village of Arlington Heights v. Metropolitan Hous. Dev. Corp., 429 U.S. 252, 262 (1977) (requiring only a showing that injury is "likely to be redressed").

30. Erwin Chemerinsky, Federal Jurisdiction $\S 2.3 .2$, at 65-66 (2d ed. 1993).

31. Thomas v. County of Los Angeles, 978 F.2d 504, 508 (9th Cir. 1992).

32. For cases illustrating this two-step analysis, see infra notes 42 and 48 . 
crimination, which is not a consideration under the current Lyons approach.

1. Policy, Practice, or Custom of Police Misconduct. - Lyons requires a showing similar to that for Section 1983 liability on the merits to demonstrate that officials authorized misconduct. ${ }^{33}$ Under Monell $v$. Department of Social Services, respondeat superior liability is not available against municipalities, and plaintiffs must show that government conduct was authorized by a final decisionmaker or that there exists a pattern or practice of government conduct. ${ }^{34}$ Similarly, the Lyons Court examined police testimony, statistics regarding past injury, and other "evidence showing a pattern of police behavior." ${ }^{\text {}}$ " Lyons also follows a line of prior Supreme Court cases in which patterns of conduct satisfied the standing requirement. ${ }^{36}$

Critics of Lyons feared that in future civil rights cases a de facto pattern would not suffice and emphasized the Court's statement that Lyons would have had to make

the incredible assertion either (1) that all police officers in Los Angeles always choke any citizen with whom they happen to have an encounter, whether for purpose of arrest, issuing a citation, or for questioning, or (2) that the City ordered or authorized police officers to act in such manner. ${ }^{37}$

33. See 42 U.S.C. $\$ 1983$ (1994). The text of Section 1983 provides in relevant part:

Every person who, under color of any statute, ordinance, regulation, custom, or usage of any State or Territory or the District of Columbia, subjects, or causes to be subjected, any citizen of the United States or other person within the jurisdiction thereof to the deprivation of any rights, privileges, or immunities secured by the Constitution and laws, shall be liable to the party injured in an action at law, suit in equity, or other proper proceeding for redress.

34. 436 U.S. 658, 694 (1978) (holding municipal government liable under Section 1983 when injuries are caused pursuant to a policy or custom, whether caused directly "by its lawmakers or by those whose edicts or acts may fairly be said to represent official policy"). Monell permits liability based on a de facto pattern, activity, or a showing of deliberate indifference to unconstitutional conduct. Circuit courts have not made explicit the parallel between Monell and Lyons. The Lyons dissent argued that injunctive relief should be based on Monell liability. See City of Los Angeles v. Lyons, 461 U.S. 95, 120 (Marshall, J., dissenting). The majority never disagreed and only stated that a policy or custom had not been alleged.

35. Lyons, 461 U.S. at 110 n.9.

36. A line of pre-Lyons cases emphasized that a pattern is sufficient ground for injunctive relief. See Allee v. Medrano, 416 U.S. 802, 815 (1974) (inferring a sufficient threat from a "persistent pattern of police misconduct"); Hague v. Committee for Indus. Org. 307 U.S. 496, 505, 517-18 (1939) (finding a deliberate policy of, inter alia, refusing to grant public meeting permits sufficient); see also Rizzo v. Goode, 423 U.S. 362, 371 (1976) (holding that standing requirements are satisfied if plaintiff can allege "any plan or policy by petitioners-express or otherwise-showing their authorization or approval of such misconduct" (emphasis added)).

37. Lyons, 461 U.S. at 106. 
Justice Marshall countered in his dissent: “[1]f the police adopt a policy of 'shoot to kill,' or a policy of shooting 1 out of 10 suspects, the federal courts will be powerless to enjoin its continuation." 38

This concern appears to be misplaced. ${ }^{39}$ The majority expressed its requirement in the disjunctive, requiring that a plaintiff make one of two alternative allegations. First, the plaintiff could allege that in every encounter with a person, police engage in the challenged conduct-admittedly an "incredible assertion." The second alternative is more realistic and asks that the plaintiff show official "authorization" of misconduct. If a plaintiff sufficiently alleges a Monell policy, practice, or custom of misconduct, a court will find that authorization is present. ${ }^{40}$

In the years since Lyons, courts have assessed credible threat by examining a police department's policy, practice, or custom. Showing a pattern of misconduct should not be unduly burdensome. Although a written or formal policy always supports standing, ${ }^{41}$ courts have held that an implied policy or a practice of conduct is also sufficient. ${ }^{42}$ Where

38. Id. at 137 (Marshall, J., dissenting).

39. Only two decisions have ever suggested that an "incredible assertion" need be made. See Chavez v. Illinois State Police, 27 F. Supp. 2d 1053, 1080 (N.D. Ill. 1998); Washington v. Vogel, 880 F. Supp. 1542, 1545 (M.D. Fla. 1995). In Chavez, plaintiffs assembled statistical evidence of racial profiling and had suffered repeated stops from state police. See Chavez, 27 F. Supp. 2d at 1064, 1069. The court nevertheless found an insufficient likelihood of future discriminatory highway stops. See id. at 1080 . The decision was an anomaly within the Seventh Circuit. See Daniels v. Southfort, 6 F.3d 482, 485 (7th Cir. 1993) ("[I]njunctive relief is appropriate in a $\$ 1983$ action where there is a persistent pattern of police misconduct ...."). In Washington, the court never addressed the issue of whether police used a racial profile, despite repeated stops. See Washington, 880 F. Supp. at 1545.

40. See Lyons, 461 U.S. at 110 n.9; see also David Cole, Obtaining Standing to Seek Equitable Relief: Taming Lyons, in Civil Rights Litigation Handbook 101, 107, 110 (1986) ("It is important to keep in mind the difference between 'ordered' and 'authorized': The former allegation would suggest that a police officer must always use a chokehold, while the latter only means that a police officer may use it.").

41. See, e.g., Deshawn E. v. Safir, 156 F.3d 340, 345 (2d Cir. 1998) (finding standing because "[i]n contrast [to Lyons], the challenged interrogation methods in this case are officially endorsed policies").

42. See id. at 344 (suggesting that a "pattern of illegality" suffices); Church v. City of Huntsville, 30 F.3d 1332, 1339 (I th Cir. 1994) (finding standing where plaintiffs alleged a policy, practice or custom of harassing homeless persons); Daniels, 6 F.3d at 485 (stating that a persistent pattern of police misconduct is sufficient ground for injunctive relief); American Postal Workers Union v. Frank, 968 F.2d I373, 1377 (1st Cir. 1992) ("In none of the Supreme Court cases addressing the question of standing to obtain equitable relief was the challenged practice a routine, daily procedure implemented as a matter of policy by the defendants."); Thomas v. County of Los Angeles, 978 F.2d 504, 508-09 (9th Cir. 1992) (finding standing where plaintiffs alleged that "misconduct was condoned and tacitly authorized by department policy makers" and repeated violations had occurred); LaDuke v. Nelson, 762 F.2d 1318, 1324 (9th Cir. 1985) (finding standing relying upon the Lyons requirement of "pattern of police behavior" (quoting Lyons, 461 U.S. at 110 n.9)); Nicacio v. INS, 768 F.2d 1133, 1136 (9th Cir. 1985) (finding that repeated 1NS highway stops were sufficient for standing); Curtis v. City of New Haven, 726 F.2d 65, 68 (2d Cir. 1984) (denying standing to challenge police use of mace, but citing Kolender and suggesting that 
some of the same plaintiffs were stopped more than once and without reasonable suspicion, they have satisfied Lyons requirements. ${ }^{43}$ Evidence of insufficient training or repeated failure to respond to complaints of abuse can also support standing. ${ }^{44}$ Racial profiling cases will generally satisfy the Lyons requirements because, by definition, they challenge a pattern or practice of unconstitutional conduct. The lesson of Lyons is not that courts will never remedy police abuse, but that vigilant documentation may be required to show a credible threat.

2. Law-Abiding Conduct. - As a second part of the post-Lyons approach, a court asks whether the plaintiff precipitated the encounter with law enforcement by engaging in avoidable, illegal behavior. The Lyons Court emphasized the slim chance that Lyons would again commit a traffic violation, again be stopped by police, and again be choked in violation of police policy. ${ }^{45}$ The Court concluded that Lyons would have to engage in illegal conduct before a similar injury could recur, and the Court refused to speculate that Lyons might again engage in illegal conduct. ${ }^{46}$ The Court recently noted in Spencer $v$. Kemna that standing was denied in Lyons because plaintiff engaged in illegal conduct. ${ }^{47}$

official authorization or repeated incidents of misconduct would support standing); Build of Buffalo, Inc. v. Sedita, 441 F.2d 284, 289 (2d Cir. 1971) (finding standing given "[d] eliberate, purposeful activity resulting in widespread police abuses and perhaps rising to the level of de facto policy"); Maryland State Conference of NAACP Branches v. Maryland Dept. of State Police, 72 F. Supp. 2d 560, 564-65 (D. Md. 1999) (finding standing where there is a policy or practice of misconduct, and distinguishing Lyons on the ground that " $[\mathrm{t}]$ be Lyons complaint, on the other hand, did not assert that there was a pattern and practice of applying chokeholds without provocation or, if it did state such a claim, the Court found it was not supported by the record").

43. See, e.g., Nicacio, 768 F.2d at 1136 ("The possibility of recurring injury ceases to be speculative when actual repeated incidents are documented.").

44. See, e.g., Thomas, 978 F.2d at 507-08 (finding standing wben plaintiffs alleged that "misconduct was condoned and tacitly authorized by department policy makers"); National Congress for Puerto Rican Rights v. City of New York, 75 F. Supp. 2d 154, 162 (S.D.N.Y. 1999) (alleging that the police failed to respond to complaints and failed to train officers).

45. City of Los Angeles v. Lyons, 461 U.S. 95, 102-03, 108 (1983).

46. See id. at 102. A faulty taillight hardly seems like an infraction so serious that law enforcement should not be held accountable for brutality. For a criticism of Lyons, see Gene R. Nichol, Jr., Rethinking Standing, 72 Cal. L. Rev. 68, 90 (1984) ("[T]he Court's recognition of injury-the cbaracterization of loss as 'personal'-depends on its sympathy for and understanding of the loss."). This requirement is especially harsh in the context of traffic stops. See Hecker, supra note 2, at 570 (noting that "almost all drivers are guilty of some minor traffic infraction"). Nonetheless, courts are reluctant to determine the point at which a law becomes too widely disregarded to be enforced. See, e.g., Whren v. United States, 517 U.S. 806, 818 (1996) (“[W]e are aware of no principle that would allow us to decide at what point a code of law becomes so expansive and so commonly violated that infraction itself can no longer be the ordinary measure of the lawfulness of enforcement.").

47. 523 U.S. 1,15 (1998). 
In contrast, most courts find standing where plaintiffs do not violate the law. ${ }^{48}$ A pattern or practice of misconduct is a serious threat where police injure law-abiding citizens engaging in routine daily activity. Racial profiling cases in which persons are stopped without the "reasonable suspicion" required by Terry $v$. Ohio ${ }^{49}$ will satisfy the credible threat standard. Where large-scale violations occur, it will also be easier to find law-abiding class representatives.

\section{Targeting Groups}

This Note proposes an alternative to the post-Lyons approach that relies exclusively on the two factors previously discussed-authorization and law-abiding conduct. Instead, when plaintiffs allege targeting by officials, courts should presume that plaintiffs face a credible threat of future injury. Targeting occurs where law-abiding individuals are singled out by officials based on a trait, such as race, national origin, or neighborhood. ${ }^{50}$ Targeting supplements the other two factors that courts have relied upon to assess credible threat because targeting is itself a kind of policy or pattern of misconduct. Further, targeting is more invidious than an ordinary policy or pattern that harms law-abiding persons. Targeting harms groups, so that only persons possessing the targeted traits

48. Most circuits have found standing and distinguish Lyons when police injure lawabiding individuals. See Church v. City of Huntsville, 30 F.3d 1332, 1338 (11th Cir. 1994) (granting homeless plaintiffs standing, since due to the "allegedly involuntary nature of their condition, the plaintiffs cannot avoid future "exposure to the challenged course of conduct' in which the City allegedly engages" (quoting O'Shea v. Littleton, 414 U.S. 488, 497 (1974))); Thomas, 978 F.2d at 508 ("In contrast [to Lyons] . . . many victims purportedly did nothing to warrant detention or apprehension prior to the mistreatment."); Hernandez v. Cremer, 913 F.2d 230, 234-35 (5th Cir. 1990) (explaining that the INS stop in question inflicted an injury which "did not result from an individual's disobedience of official instructions and [the plaintiff] was not engaged in any form of misconduct"); LaDuke v. Nelson, 762 F.2d 1318, 1326 (9th Cir. 1985) (finding standing because "the members of plaintiff class do not have to induce a police encounter before the possibility of injury can occur. . . The class members are subject to constitutional injury based on ... completely innocent behavior . . . ."); Farm Labor Org. Comm. v. Ohio State Highway Patrol, 95 F. Supp. 2d 723, 731 n.6 (N.D. Ohio 2000) (denying standing where "no stop of any plaintiff in this case has been shown to have occurred without antecedent observation of a traffic violation, and, significantly, there has been no evidence of racial profiling in the initial stopping of Hispanic motorists"); National Congress for Puerto Rican Rights v. City of New York, 75 F. Supp. 2d at 161 ("The fact that plaintiffs were stopped while engaging in everyday tasks further illustrates a realistic risk of future harm."); Franklin v. City of Chicago, 102 F.R.D. 944, 948 (N.D. Ill. 1984) (granting standing for injunctive relief where plaintiffs were arrested, but alleged a policy of arrests without probable cause).

49. 392 U.S. 1, 20, 25-27 (1968) (holding that while an arrest requires probable cause, an officer's reasonable suspicion can justify a stop and frisk).

50. I use the word targeting and not profiling, since targeting implies that a single trait has been singled out for disparate treatment, while profiling implies a list of factors or a suspect "profile." 
face an enhanced threat. ${ }^{51}$ For example, in a racial profiling case where police disparately stop Latino motorists without reasonable suspicion, plaintiffs would allege that police engaged in a pattern of misconduct and that plaintiffs violated no laws. Moreover, the threat to Latino motorists as a group is enhanced because Latino persons are singled out for injury.

The most serious obstacle to a targeting theory of standing for injunctive relief is the Lyons decision itself. The Lyons Court never discussed race, giving some commentators the impression that the Court was insensitive to the reality of racism in policing. ${ }^{52}$ Lyons was black, and in his equal protection claim he alleged that minorities were the disparate victims of LAPD chokeholds; his allegation seemed plausible, since threefourths of those killed by the chokeholds were black. ${ }^{53}$ The dissent strongly rebuked the Court for ignoring this evidence. ${ }^{54}$ The Lyons Court's silence on race is unfortunate; however, because Lyons could not show that a policy or practice authorized his chokehold in the first instance, the Court never reached the question of whether such a policy or practice was discriminatory.

In recent years, courts have relied upon the Lyons Court's reasoning to justify treating targeting cases differently. In Honig $v$. Doe, the Supreme Court stated that Lyons should be distinguished where individuals are targeted by a government policy. ${ }^{55}$ The Honig Court dispensed with Lyons with little discussion, but did note that Lyons should not apply where plaintiff was targeted because of his disability. Additionally, several lower courts have intimated that Lyons's requirements may be satisfied where racial targeting occurs. Specifically, courts have considered racebased targeting a factor supporting standing, but have not taken the next

51. For an argument that targeting is itself a serious Fourth Amendment injury, see Sherry F. Colb, Innocence, Privacy, and Targeting in Fourth Amendment Jurisprudence, 96 Colum. L. Rev. 1456, 1487-88 (1996) (arguing that "the targeting feature of the officer's conduct comes to occupy as significant a place in the doctrine as the intrusion itself," since being "singled out" because one is different is itself harmful).

52. See Cole, No Equal Justice, supra note 3, at 165 ("[T] he illusion is maintained that the system forbids discrimination; the reality is that the system for all practical purposes forbids discrimination cases."); 1982 Term, supra note 8, at 223 ("The Lyons Court belittled-by ignoring-the seriousness of the police brutality faced by blacks in this country.").

53. See Cole, No Equal Justice, supra note 3, at 162.

54. See City of Los Angeles v. Lyons, 461 U.S. 95, 114, 116 n.3 (Marshall, J., dissenting) ("Thus in a City where Negro males constitute $9 \%$ of the population, they have accounted for $75 \%$ of the deaths resulting from the use of chokeholds. In addition to his other allegations, Lyons alleged racial discrimination . . ...").

55. 484 U.S. 305, 322 (1988) (emphasizing in a discussion of mootness that Lyons is inapplicable where state policies injure individuals based on immutable characteristics); see also Church v. City of Huntsville, 30 F.3d 1332, 1338 (11th Cir. 1994) (finding that homeless victims of police harassment had standing, since due to the "allegedly involuntary nature of their condition, the plaintiffs cannot avoid future 'exposure to the challenged course of conduct' in which the City allegedly engages" (quoting O'Shea v. Littleton, 414 U.S. 488, 497 (1974))). 
logical step and explained why the presence of targeting should itself support standing. For example, the Thomas court stated, "[m]oreover, plaintiffs have alleged that the misconduct is purposefully aimed at minorities." 56

In racial profiling cases, the threat of future harm to minorities is greater because a pattern of enforcement singles out persons based on suspect criteria. ${ }^{57}$ The threat to plaintiffs is similarly enhanced if neighborhoods are targeted, as neighborhoods can often be used as a proxy for race. ${ }^{58}$ Worse, when police target minority neighborhoods, residents cannot avoid injury without curtailing routine activities near their homes.

Even if courts incorporate targeting as a factor within the Lyons framework, analysis would still proceed by assessing the credible threat and likelihood of future injury faced by an individual plaintiff. The Lyons framework is thus a limited inquiry, focusing exclusively on an individual's likelihood of future harm. Racial profiling cases involve claims of discrimination, and the Lyons approach sidesteps the equal protection values that are implicated when members of a group are singled out based on suspect criteria. For this reason, Part 11 of this Note suggests that

56. Thomas v. County of Los Angeles, 978 F.2d 504, 508 (9th Cir. 1992) (emphasizing that plaintiffs alleged a racially discriminatory pattern of police brutality that "is purposefully aimed at minorities"); see also. Hodgers-Durgin v. De La Vina, 199 F.3d 1037, 1047 (9th Cir. 1999) (Reinhardt, J., concurring) ("[T] he entitlement asserted-the right to be free from race-based governmental discrimination in general and from searches and seizures based on race in particular-is constitutionally mandated."); Gonzales v. City of Peoria, 722 F.2d 468, 481 (9th Cir. 1983) (finding standing where "officers make a practice, based on city policy, of violating the constitutional rights of [city] residents of Mexican descent, and that this policy is consistently applied to drivers and passengers of vehicles stopped for traffic violations"); Maryland State Conference of NAACP Branches v. Maryland Dept. of State Police, 72 F. Supp. 2d 560, 565 (D. Md. 1999) ("[T] he plaintiffs' likelihood of injury depends only on their status as a member of a minority group and their need to travel on I-95.”); Gomez v. City of West Chicago, 506 F. Supp. 1241, 1243 (N.D. Ill. 1981) (finding standing where "treatment has been directed against plaintiffs solely because of their race and national origin").

57. For example, a credible threat should be found if in a given highway corridor plaintiffs may be subject to an ongoing practice of racial profiling. See Hodgers-Durgin v. De La Vina, 165 F.3d 667, 674 (9th Cir. 1999), rev'd en banc, 199 F.3d 1037 (9th Cir. 1999) ("Plaintiffs merely must embark on a routine journey and pass a Border Patrol agent who, pursuant to the alleged pattern and practice, decides to stop them for no legitimate reason. . . . a credible threat of future injury hangs over Plaintiffs' heads every time they drive on these highways."); Nicacio v. INS, 768 F.2d 1133, 1136 (9th Cir. 1985) (holding that repeated INS stops were sufficient for standing since " $[t]$ he possibility of recurring injury ceases to be speculative when actual repeated incidents are documented").

58. See United States v. Montero-Camargo, 208 F.3d 1122, 1138 (9th Cir. 2000) (noting that "an individual's presence in a high crime area is not enough to support reasonable, particularized suspicion"); Thomas v. County of Los Angeles, 978 F.2d 504, 508 (9th Cir. 1992) (stating that "police misconduct . . . occurred in a small six hy seven block area."); see also Jerome H. Skolnick, Justice Without Trial: Law Enforcement in Democratic Society 218 (2d ed. 1975) (noting cases where "the basis for declaring an area crime-prone may be flimsy" and where police targeted individuals that did not meet the profile of the allegedly prevalent crime). 
courts should do more than treat targeting as a Lyons factor and take the next step of distinguishing Lyons in racial profiling cases, as the Supreme Court suggested in Honig $v$. Doe.

\section{Standing Based on Group-Based Harm in Racial Profiling Cases}

This Part proposes an approach to standing in racial profiling cases predicated on a theory of group-based harm. The first section discusses equal protection doctrine in racial profiling cases and defines the groupbased harm created by racial profiling. The next section argues that based on a series of equal protection cases, the Lyons decision should be distinguished where plaintiffs suffer group-based harm. Finally, voting rights cases suggest a political-process theory of standing for injunctive relief that may explain why the Court grants standing more expansively where plaintiffs allege group-based harm.

\section{A. Racial Profiling and Equal Protection}

The term "racial profiling" provides powerful rhetoric, aptly expressing the underlying problem of racial injustice, and has consequently gained currency in recent years. Surprisingly though, until recently, lawsuits involving police stops seldom emphasized race discrimination claims under the Equal Protection Clause, and rested upon alleged violations of Fourth Amendment rights. Practitioners may not have focused on race because intentional discrimination was considered prohibitively difficult to establish. Since the Supreme Court's decision in Whren v. United States, Fourth Amendment case law now appears to be the greater obstacle to suits and practitioners may increasingly focus on pursuing Fourteenth Amendment claims. ${ }^{59}$ Courts may begin to apply strict scrutiny in racial

59. 517 U.S. 806,813 (1996) (holding that a pretextual traffic stop did not violate the Fourth Amendment, but suggesting in dicta that "selective enforcement of the law based on considerations such as race" might violate the Equal Protection Clause). The Supreme Court has held that under the Fourth Amendment, race can reasonably be included in a suspect profile, as long as race is one of several factors used. See United States v. MartinezFuerte, 428 U.S. 543, 563 (1976) (permitting discretion to use "apparent Mexican ancestry" to support reasonable suspicion); United States v. Brignoni-Ponce, 422 U.S. 873, $886-87$ (1975) ("The likelihood that any given person of Mexican ancestry is an alien is high enough to make Mexican appearance a relevant factor . . . ."); United States v. Collins, 532 F.2d 79, 82 (8th Cir. 1976) (“[T]he color of a person's skin . . . is an identifying factor which . . . assists the police in narrowing the scope of their identification procedure."). The Court's decision in Illinois $v$. Wardlow further weakens Fourth Amendment protections, finding reasonable suspicion to stop and frisk persons merely fleeing police. $120 \mathrm{~S}$. Ct. 673, 673 (2000). For a strong argument that race-based stops are not permissible under the Fourth Amendment, see Montero-Camargo, 208 F.3d at 1134 n.22:

[Race] may be considered when the suspected perpetrator of a specific offense has been identified as having such an appearance. Even in such circumstances, however, persons of a particular racial or ethnic group may not be stopped and questioned because of sucb appearance, unless there are other individualized or particularized factors which . . . rise to the level of reasonable suspicion or probable cause. To the extent that our prior cases have approved the use of 
profiling challenges. Although few courts have considered the issue, racial profiling case law is evolving rapidly. Recent district court decisions in the Second and Ninth Circuits have for the first time upheld equal protection claims in racial profiling challenges. ${ }^{60}$

Hispanic appearance as a factor where there was no particularized, individual suspicion, they are overruled.

Many commentators fear that the equal protection requirement that plaintiffs show intentional discrimination creates a fatal obstacle to private lawsuits because police are often motivated by "unconscious" racism. See David A. Sklansky, Traffic Stops, Minority Motorists, and the Future of the Fourth Amendment, 1997 Sup. Ct. Rev. 271, 326:

Equal protection doctrine ... gives no recognition to the special reasons to insist on evenhanded law enforcement, or to the distinctive concerns with arbitrariness underlying the Fourth Amendment. As a result, challenges to discriminatory police practices will fail without proof of conscious racial animus on the part of the police. ... [T] $\mathrm{T}$ his amounts to saying that they will almost always fail.

See also David A. Harris, "Driving While Black" And All Other Traffic Offenses: The Supreme Court and Pretextual Traffic Stops, 87 J. Crim. L. \& Criminology 544, 576-79 (1997) (discussing how after Whren, judicial remedies may be impossible and a better hope may be police self-regulation and monitoring); Sheri Lynn Johnson, Race and the Decision To Detain a Suspect, 93 Yale L.J. 214, 226-30 (1983) (concluding that courts are too willing to accept use of race in policing).

Given the number of factors that can play a role in a police stop, it may be difficult to show that race is the predominant factor in any one police stop, much less infer a discriminatory purpose from a pattern of stops. Police can show that stops were based on pretextual traffic violations, unobjectionable assignment of officers to "high crime" neighborhoods, class, or use of legitimate descriptions of individual suspects. For example, the Second Circuit, in Brown v. City of Oneonta, recently held that to show an equal protection violation, plaintiffs must show that stops were made "solely on the basis of their race." 221 F.3d 329, 337 (2d Cir. 2000). A police sweep was not solely based on race where police relied only upon "a physical description given by the victim of a crime," which included "race, ... gender and age, as well as the possibility of a cut on the hand." 1d. But see United States v. Scopo, 19 F.3d 777, 786 (2d Cir. 1994) (Newman, C.J., concurring) (arguing that though the Fourth Amendment permits pretextual stops, selective stops based on race can create an Equal Protection violation).

It may be too soon to conclude that equal protection claims will always fail. Racially disparate profiling may be so egregious in some cases that discriminatory purpose may be inferred. See Yick Wo v. Hopkins, 118 U.S. 356, 374 (1886). Regardless, standing analysis should be untouched by such concerns about the merits. For the purposes of standing, an allegation that police engage in a practice of racial profiling should be sufficient, since under Leatherman v. Tarrant County, determination of whether a classification exists must be reserved for the merits. 507 U.S. 164, 168 (1993) (holding that heightened pleading cannot be required in civil rights cases, or in cases where specificity is not required as stated in Fed. R. Civ. P. 9(b)); see also Lujan v. Defenders of Wildlife, 504 U.S. 555, 561 (1992) ("At the pleading stage, general factual allegations of injury resulting from the defendant's conduct may suffice, for on a motion to dismiss we 'presum[e] that general allegations embrace those specific facts that are necessary to support the claim." (quoting Lujan v. National Wildlife Fed'n, 497 U.S. 871, 889 (1990)).

60. See Rodrignez v. California Highway Patrol, 89 F. Supp. 2d 1131, 1141 (N.D. Cal. 2000) (finding that plaintiffs stated an equal protection claim by alleging that "Defendants acted with discriminatory intent and that Defendants knew about but refused to stop racially discriminatory practices on the part of their officers and by alleging the existence of statistical evidence and other facts which if proved would support an inference of discriminatory intent."); National Congress for Puerto Rican Rights v. City of New York, 191 F.R.D. 52, 53 (S.D.N.Y. 1999) (reinstating equal protection claims in a racial profiling 
Although racial profiling creates a kind of racial classification, where individuals are targeted for different treatment based on a racially motivated policy or practice, ${ }^{61}$ plaintiffs cannot generally point to rules that "expressly classif[y] persons on the basis of race."62 Unlike race-explicit drug courier profiles, ordinances and police rules for stopping individuals typically are facially neutral. The Court has held, however, that race cannot be a "motivating factor" 63 in a state decision. In some cases, plaintiffs may be able to show a racial disparity so dramatic that an inference of intentional discrimination can be made, as in Yick Wo v. Hopkins. ${ }^{64}$ Equal protection claims may also be able to succeed merely by showing disparate impact under Title VI of the Civil Rights Act of 1964.65 While this

class action against the Street Crimes Unit of the New York City Police Department, finding strict scrutiny appropriate at least for the purpose of a motion to dismiss); see also Wilson v. Tinicum Township, No. 92-6617, 1993 WL 280205, at *7 (E.D. Pa. July 20, 1993) (certifying class for injunctive relief in racial profiling case alleging both Fourth and Fourteenth Amendment violations).

The alternative to applying strict scrutiny would be to treat such cases as selective prosecution cases, where plaintiffs bear the burden of identifying similarly situated individuals of other races who did not suffer misconduct. See U.S. v. Armstrong, 517 U.S. 456, 465 (1996) (requiring plaintiffs to identify such similarly situated individuals). This approach has been largely rejected by courts, and only one court has applied Armstrong in a racial profiling case. Compare Brown v. City of Oneonta, 221 F.3d at 337 (" $[1] \mathrm{t}$ is not necessary to plead the existence of a similarly situated non-minority group when challenging a law or policy that contains an express, racial classification"), Rodriguez, $89 \mathrm{~F}$. Supp. 2d at 1141 (rejecting application of selective prosecution doctrine, and upholding equal protection claims), National Congress for Puerto Rican Rights, 191 F.R.D. at 52 (rejecting application of selective prosecution doctrine), with Chavez v. 1llinois State Police, 27 F. Supp. 2d 1053, 1066-67 (N.D. 1ll. 1998) (applying selective prosecution doctrine to law enforcement and dismissing equal protection claims). Several commentators argue that policing cases in which individuals are selectively injured by violations of the law are not analogous to selective prosecution cases in which prosecution is itself legal. See Carl. J. Schifferle, After Whren v. United States: Applying the Equal Protection Clause to Racially Discriminatory Enforcement of the Law, 2 Mich. L. \& Pol'y Rev. 159 (1997) (arguing that a prima facie case of discrimination need not include information on similarly situated offenders); Christopher Hall, Challenging Selective Enforcement of Traffic Regulations After the Disharmonic Convergence: Whren v. United States, United States v. Armstrong, and the Evolution of Police Discretion, 76 Tex. L. Rev. 1083,1114 (1998) (arguing that unlike prosecution, unconstitutional police conduct does not enjoy "wide, court-sanctioned discretion").

61. See Sheri Lynn Johnson, supra note 59, at 244-45 ("[U]sing racial incongruity as a factor in determining probable cause should also be subject to strict scrutiny.").

62. Adarand Constructors, Inc. v. Pena, 515 U.S. 200, 213 (1995).

63. Village of Arlington Heights v. Metropolitan Housing Dev. Corp., 429 U.S. 252, 265-66 (1977) ("[Washington v.] Davis does not require a plaintiff to prove that the challenged action rested solely on racially discriminatory purposes. . . When there is proof that a discriminatory purpose has been a motivating factor in the decision, this judicial deference is no longer justified.").

64. 118 U.S. 356 (1886) (inferring intentional discrimination from disparate enforcement of an ordinance banning laundries against Chinese Americans).

65. 42 U.S.C. $\$ 2000 \mathrm{~d}$ (1994) provides that:

No person in the United States shall, on the ground of race, color, or national origin, be excluded from participation in, be denied the benefits of, or be 
avenue remains novel and largely untested, courts have held that Title VI permits a private right of action for individuals to seek injunctions against recipients of federal funding, including local police, given a policy or practice that discriminates on the basis of race. ${ }^{66}$

Courts applying equal protection doctrine to racial profiling cases must consider strict scrutiny where a racial classification is created by what is termed a "group-based harm."67 A group-based harm is simply a harm suffered because of inclusion in a group and, in the case of racial profiling, because of inclusion in a suspect group. Group harm is always present where a racial classification is made because classifications them-

subjected to discrimination under any program or activity receiving Federal financial assistance.

Local police departments receive funding from the Department of Justice and are subject to the Department of Justice's implementation regulations for Title VI, which state that recipients may not "utilize criteria or methods of administration which have the effect of subjecting individuals to discrimination because of their race, color, or national origin, or have the effect of defeating or substantially impairing accomplishment of the objectives of the program as respects individuals of a particular race, color, or national origin." 28 C.F.R. § 42.104(b) (2) (1999).

66. See Rodriguez v. California Highway Patrol, 89 F. Supp. 2d 1131, 1139 (N.D. Cal. 2000) (finding that plaintiffs adequately pled a Title VI claim by alleging that the police department receives federal funding and engages in "racial discrimination by stopping, detaining, interrogating and searching motorists on the basis of race"); Maryland State Conference of NAACP Branches v. Maryland Dep't. of State Police, 72 F. Supp. 2d 560, 566-67 (D. Md. 1999) (finding that a private right of action exists under Title VI and that plaintiffs alleging a practice of racial profiling have adequately stated a claim).

The existence of a private right of action under Title VI remains uncertain. See Sandoval v. Hagan, 7 F. Supp. 2d 1234, 1252 (M.D. Ala. 1998) (holding that a private right of action is available). Sandoval followed the Third Circuit in Chester Residents Concerned for Quality Living $v$. Seif, finding a private right of action, but Chester was vacated by the Supreme Court as moot, without addressing the existence of the private right of action. See Chester, 132 F.3d 925, 937 (3d Cir. 1997), vacated as moot, 524 U.S. 974 (1998). A majority of justices have agreed in dicta that a private right of action existed under Title VI. See, e.g., Guardians Ass'n v. Civil Serv. Comm'n of New York, 463 U.S. 582, 635 (1983) (Stevens, J., dissenting) (“[A]t least eight members of this Court have endorsed the view that Title VI ... may be enforced in a private action ...."). However, many fear that under the Court's more restrictive view of implying rights of action, today's Court would not uphold a private right. See, e.g., Thompson v. Thompson, 484 U.S. 174, 192 (1988) (Scalia, J., concurring) (calling for a "flat rule that private rights of action will not be implied in statutes hereafter enacted"); Touche Ross \& Co. v. Redington, 442 U.S. 560, 574-76 (1979) (treating the inquiry into the existence of a private right of action as a narrow one of statutory interpretation).

67. See John Hart Ely, If at First You Don't Succeed, Iguore the Question Next Time? Group Harm in Browm v. Board of Education and Loving v. Virginia, 15 Const. Comment 215, 220 (1998) [hereinafter Ely, Group Harm] (articulating a group-based harm theory that reconciles several of the Supreme Court's major equal protection decisions). A case which the Supreme Court recently affirmed suggests that not all equal protection cases are groupbased, and one individual can suffer an equal protection violation where that individual suffers targeting. See Olech v. Village of Willowbrook, 160 F.3d 386, 387-88 (7th Cir. 1998), aff'd, I20 S. Ct. I073 (2000) (explaining that equal protection claim was properly stated where one homeowner was not provided with water for three months due to ill will resulting from a previous lawsuit against the Village). 
selves segregate individuals into groups. Classifications are "race-based presumptions [used] in identifying . . . individuals." 68 Supreme Court decisions emphasize that racial classifications demand strict scrutiny: "[T] he Equal Protection Clause demands that racial classifications . . . be subjected to the "most rigid scrutiny," "69 because "[d]istinctions between citizens solely because of their ancestry are by their very nature odious."70

Racial profiling harms groups in especially invidious ways because the racial classification is compounded by a threat to physical safety. An encounter with police engaging in profiling is what some term a "racemaking situation," 71 where victims of a racially motivated stop understand that they have been singled out because of their race. The outrage that has fueled the "driving while black" debate may stem from the stigmatization and psychological harm that results from being targeted because of race, as well as the fear that racially motivated stops can escalate into abusive or even life-threatening encounters. ${ }^{72}$ Social scientists have documented that this psychological harm leads to loss of belief in the legitimacy of government and that racial profiling may induce segregation if minorities must engage in defensive "survival techniques" to avoid police, public places, or white neighborhoods for fear of being stopped. ${ }^{73}$ The equal protection harm is further compounded by the fact that most of

68. Adarand Constructors, Inc. v. Pena, 515 U.S. 200, 204 (1995).

69. Loving v. Virginia, 388 U.S. 1, 11 (1967) (quoting Korematsu v. United States, 323 U.S. 214,216 (1944)). Adarand held that "all racial classifications, imposed by whatever ... government actor, must be analyzed by a reviewing court under strict scrutiny." 515 U.S. at 227; see also City of Richmond v. Croson, 488 U.S. 469, 493 (1989) (stating that "[c]lassifications based on race carry a danger of stigmatic harm," regardless of whether they are designed to serve benign or remedial goals); Fullilove v. Klutznick, 448 U.S. 448, 537 (1980) (Stevens, J., dissenting) ("Racial classifications are simply too pernicious to permit any but the most exact connection between justification and classification.").

70. Adarand, 515 U.S. at 215 (quoting Hirabayashi v. United States, 320 U.S. 81, 100 (1943)).

71. David R. James, The Racial Ghetto as a Race-making Situation: The Effects of Residential Segregation on Racial 1nequalities and Racial Identity, 19 L. \& Soc. Inquiry 407, 420-29 (1994).

72. Double stigmatization of the victim as criminal and as a minority leads to a perception of law enforcement as unfair; traumatic encounters with police can shatter trust and belief in the fundamental legitimacy of government. See United States v. Berrios, 501 F.2d 1207, 1209 (2d Cir. 1974) ("Nothing can corrode respect for a rule of law more than the knowledge that the government looks beyond the law itself to arbitrary considerations, such as race . . . as the basis for determining its applicability."); Spitzer, supra note 2, at 76-87 (relating experiences of psychological harm by persons stopped by the New York Police Department because of their race); David Cole, What's Criminology Got To Do With It?, 48 Stan. L. Rev. 1605, 1621-22 (1996) ("Polls have consistently shown that the majority of black citizens feel that the criminal justice system does not treat them fairly.... [This] undermines law enforcement efforts that rely on community cooperation."); David A. Harris, The Stories, the Statistics, and the Law: Why "Driving While Black" Matters, 84 Minn. L. Rev. 265, 309 (1999) (noting how pretextual traffic stops undermine trust needed for effective community policing).

73. See Hecker, supra note 2, at 552 (describing "survival techniques"); Johnson, supra note 59, at 245 : 
these stops single out young, teenage men in discrete, usually poor, neighborhoods. ${ }^{74}$

\section{B. Standing in Equal Protection Cases}

Lyons's standing requirements should not apply where a suspect group has been targeted. Although no cases have explicitly distinguished Lyons in this manner, several of the Supreme Court's equal protection decisions have distinguished Lyons implicitly by holding that group harm is itself sufficient to establish standing where plaintiffs would otherwise fail to satisfy Lyons requirements. ${ }^{75}$

The Lyons opinion itself suggested that its requirements do not apply where plaintiffs allege group-based harm. The Lyons Court added requirements to the typical injury in fact requirement because Lyons could only show an undifferentiated injury no more acute than that of "any other citizen of Los Angeles."76 This aspect of the decision seemed hard to place because the Court was operating at the penumbra of standing doctrine, relying upon the so-called "prudential" doctrine that grounds justiciability requirements. The majority relied upon a line of decisions holding that for prudential reasons, a citizen may not assert "generalized grievances" about widely diffused, abstract injuries that are suffered by any member of the public at large. ${ }^{77}$

Even if it were not more burdensome to blacks than to whites, police action based upon racial incongruity should invoke strict scrutiny because it fosters racial separation. Stopping blacks in white neighborhoods and whites in black neighborhoods when their conduct alone does not justify detention will discourage people from socializing or living outside their own racial group, possibly conveying social stigma and fostering stereotypes.

See also Tom R. Tyler, Why People Obey the Law, 170-73 (1990) (showing how belief in the legitimacy of legal authorities determines compliance with law).

74. See, e.g., David A. Harris, Factors for Reasonable Suspicion: When Black and Poor Means Stopped and Frisked, 69 Ind. L.J. 659, 659-60 (1994) (describing how racial profiling disparately affects young, male, minority inner-city residents).

75. See infra text accompanying notes 80-95.

76. City of Los Angeles v. Lyons, 461 U.S. 95, 111 (1983). For a critical approach, see Steven L. Winter, The Metaphor of Standing and the Problem of Self-Governance, 40 Stan. L. Rev. 1371, 1510 (1988) (criticizing the Lyons Court's retreat from a broader approach towards public law litigation, arguing that the Court artificially "disaggregated individuals who shared an important, life-or-death interest" in preventing the practice):

That he had been choked once nearly to death was irrelevant because, in the Court's view, that fact did not address the likelihood that $M r$. Lyons might be subjected to a chokehold again. That others were dying while the case continued was irrelevant. Also irrelevant was that they too could not be present because the police had not yet chosen them as victims.

See also Fallon, Of Justiciability, supra note 19, at 23 ("Defying implicit policies of emerging public law, [Lyons] also diminishes the power of courts, and potentially the capacity of Congress, to protect federal rights and to provide remedies for their violation.").

77. Warth v. Seldin, 422 U.S. 490, 499, 510 (1975) (“[W] hen the asserted harm is a 'generalized grievance' shared in substantially equal measure by all or a large class of citizens, that harm alone normally does not warrant exercise of jurisdiction."); see also 
Thus, the Court required Lyons to show likelihood of future harm because, absent a policy or pattern of misconduct, Lyons was a solitary injured individual and not part of any group of similarly situated individuals facing a real danger of future harm. An individualized showing of future likelihood of harm is sensible in cases involving an individual encounter, but an individualized showing is not relevant in racial profiling cases where the harm alleged is group-based. ${ }^{78}$ Had group harm been shown, by demonstrating that police followed a common policy or practice of repeatedly harming persons, injunctive relief could have been pursued. ${ }^{79}$

Supreme Court equal protection cases provide additional support for distinguishing Lyons where group-based harm is alleged. Leading Supreme Court cases appear to distinguish Lyons implicitly. While commentators have not made this claim, several have noted that standing analysis looks different in equal protection cases. ${ }^{80}$ In many of the Court's equal protection decisions, standing for injunctive relief is found where plaintiffs allege that due to a suspect classification they face a reduced oppor-

Valley Forge Christian College v. Americans United for Separation of Church and State, Inc., 454 U.S. 464, 474-75 (1981) (holding that courts should refrain from adjudicating questions of injury that are "pervasively shared and most appropriately addressed in the representative branches"); Gladstone, Realtors v. Village of Bellwood, 441 U.S. 91, 99-100 (1979) ( $[\mathrm{T}]$ he judiciary seeks to avoid deciding questions of broad social import where no individual rights would be vindicated and to limit access to the federal courts to those litigants best suited to assert a particular claim."); Schlesinger v. Reservists Comm. to Stop the War, 418 U.S. 208, 220 (1974) ("standing to sue may not be predicated upon an interest . . . held in common by all members of the public, because of the necessarily abstract nature of the injury all citizens share"); United States v. Richardson, 418 U.S. 166, 167-70 (1974) (denying plaintiffs standing to challenge Central Intelligence Agency failure to disclose operating expenses for prudential reasons); Flast v. Cohen, 392 U.S. 83, 106 (1968) (permitting standing in a taxpayer suit alleging violation of separation between church and state, but affirming the strict requirement of a personal stake in the outcome of litigation); Perkins v. Lukens Steel Co., 310 U.S. 113, 125 (1940) (denying standing where plaintiffs could not show injury to "a particular right of their own, as distinguished from the public's interest in the administration of the law").

78. For a case distinguishing Lyons where a group-based harm was not based on a suspect classification, see Church v. City of Huntsville, 30 F.3d 1332, 1338 (11th Cir. 1994) (finding that homeless victims of a police harassment campaign had standing, since due to the "involuntary nature of their condition, the plaintiffs cannot avoid future 'exposure to the challenged course of conduct' in which the City allegedly engages" (quoting O'Shea v. Littleton, 414 U.S. 488, 497 (1974))).

79. See Lyons, 461 U.S. at 110 n.9, 111.

80. See, e.g., Cass R. Sunstein, What's Standing After Lujan? Of Citizen Suits, "Injuries," and Article III, 91 Mich. L. Rev. 163, 203-05 (1992) (arguing that Bakke and other major equal protection decisions improperly find or deny standing based only on the Court's characterization of the opportunity denied to the plaintiff); see also Girardeau A. Spann, Color-Coded Standing, 80 Cornell L. Rev. 1422, 1465 (1995) ("[I]t is difficult to imagine anyone seriously disputing the fact that the Court is much more likely to reject a programmatic racial discrimination challenge on standing grounds when the plaintiff is a minority plaintiff .....). 
tunity to compete for a job or some other benefit. ${ }^{81}$ There is no required additional showing that one would "realistically" or "credibly" obtain the benefit. ${ }^{82}$

Landmark equal protection decisions involving race or sex-based classifications brush over issues of future harm. For example, in Heckler $v$. Mathews, men had standing to challenge a health benefit provided only to women, though they may not have tangibly benefited if the state remedied the inequality by eliminating the benefit altogether. ${ }^{83}$ The Court stated:

[W] e have never suggested that the injuries caused by a constitutionally underinclusive scheme can be remedied only by extending the program's benefits to the excluded class. . . . [W]e have frequently entertained attacks on discriminatory statutes or practices even when the government could deprive a successful plaintiff of any monetary relief by withdrawing the statute's benefits from both the favored and the excluded class. ${ }^{84}$

Similarly, in Adarand Constructors, Inc. v. Pena, standing was satisfied given an allegation of a racial classification, a pattern of past participation in construction bidding, and a bare statement of intention to participate in the future. ${ }^{85}$ While Lyons could not state an intention to violate traffic laws in the future, plaintiffs in racial profiling cases can allege a racial classification and an intention to continue engaging in the innocent activity that leads to a police stop.

81. See, e.g., Clements v. Fashing, 457 U.S. 957, 962 (1982) (finding standing in equal protection challenge to law requiring resignation upon announcing candidacy for another office, stating that discouraging potential candidacy was sufficient and no allegation of future candidacy was required); Orr v. Orr, 440 U.S. 268, 272 (1978) (standing found in husband's challenge to alimony scheme preferring dependent spouses, though a remedy might deny benefit to both men and women); Regents of Univ. of Cal. v. Bakke, 438 U.S. 265,320 (1978) (addressing standing issues and concluding that the school policy denied Bakke an opportunity to compete for a spot in the school, and that a showing that he would be admitted without the policy was not necessary); Stanton v. Stanton, 421 U.S. 7, 17-18 (1975) (finding standing to challenge in which child support payments for women accrued at an age of majority of 18 , but for men at 21 , though the remedy might be to deny privileges to women until 21); Turner v. Fouche, 396 U.S. 346, 364 (1970) (concluding plaintiff had standing to challenge law limiting school board membership to property owners, though plaintiff did not own property); Smith v. City of Cleveland Heights, 760 F.2d 720, 722 (6th Cir. 1985) (finding standing because of stigmatic injury where racial steering denied minority plaintiffs an equal opportunity to apply for housing in that community).

82. The Court suggests that classifications harm groups independent of the actual benefit or burden applied. "Racial classification, whether providing benefits to or burdening particular racial or ethnic groups, may stigmatize those groups singled out for differential treatment and may create considerable tension with the Nation's widely shared commitment to evaluating individuals upon their individual merit." Metro Broadcasting, Inc. v. FCC, 497 U.S. 547, 604 (1990) (O'Connor, J., dissenting).

83. 465 U.S. 728 (1984).

84. Id. at $738-39$.

85. 515 U.S. $200,211-12$ (1995). 
Northeastern Florida Chapter of the Associated General Contractors of America v. City of Jacksonville illustrates the Court's approach to standing in equal protection cases. ${ }^{86}$ Breaking its usual silence, the Court compared a range of equal protection cases in which standing was disputed. The Court concluded that it sufficed to include only an allegation that discrimination resulted from an affirmative action policy for distributing contracts and that plaintiffs had previously applied for a contract. The Court emphasized that equal protection cases share a common threadthat group-based harm to a suspect group suffices for standing:

Singly and collectively, these cases stand for the following proposition: When the government erects a barrier that makes it more difficult for members of one group to obtain a benefit than it is for members of another group, a member of the former group seeking to challenge the barrier need not allege that he would have obtained the benefit but for the barrier in order to establish standing. The "injury in fact" in an equal protection case of this variety is the denial of equal treatment $\ldots .8^{87}$

The Court assumes a future harm in an equal protection case and requires a racial classification that denied equal treatment in the past. The only limitation on standing in equal protection cases is that plaintiffs must allege that they were "personally subject to the challenged discrimination" 88 or "hav[e] personally been denied equal treatment." 89 This limitation turns out to be almost no limitation at all in an equal protection case, where being personally subject to discrimination means only that one suffers a group harm, or the racial classification, so that one is not just asserting a "generalized grievance."

Being "personally" subject to discrimination is not at all like the individualized likelihood of future harm that plaintiffs must show in Lyons cases. Showing that the plaintiff was personally denied equal treatment requires only that the racial classification affected the plaintiff in the past, and not in the future. In several of these cases, even the past harm seems attenuated when compared to the sorts of harm suffered in many racial discrimination cases. For example, in Northeastern Florida, the Court required a minimal allegation that the racial classification affected plaintiff, distinguishing Warth $v$. Seldin, in which the construction association "did not allege that 'any member ha[d] applied . . for a building permit or a variance with respect to any current project." "90 A simple allegation of intention to be subject to the discrimination, not even an actual denial of equal treatment, would be enough to satisfy the injury requirement-the Court states that to establish standing a party need only demonstrate "that it is able and ready to bid on contracts and that a discriminatory

86. 508 U.S. 656 (1993).

87. Id. at 666 .

88. Allen v. Wright, 468 U.S. 737, 755 (1984) (citing O'Shea v. Littleton, 414 U.S. 488

(1974) and Rizzo v. Goode, 423 U.S. 362 (1976)).

89. Id. (quoting Heckler v. Mathews, 465 U.S. 728, 740 (1984)).

90. 508 U.S. at 668 (quoting Warth v. Seldin, 422 U.S. 490,516 (1975)). 
policy prevents it from doing so on an equal basis."91 Similarly, Heckler only required that a classification somehow affected the plaintiff in the past. In Havens Realty Corp. v. Coleman, standing was granted to a black "tester" who had no intention of purchasing housing at any time in the future, but had been once denied an equal opportunity to receive information about housing. ${ }^{92}$

Allen v. Wright also supports distinguishing Lyons where an equal protection violation is alleged.93 Allen states that standing should only be denied in cases like Rizzo and O'Shea where plaintiffs were not personally subject to the harm alleged. ${ }^{94}$ Tellingly, the Court does not cite Lyons. Far from alleging a policy subjecting them to racial discrimination, plaintiffs in Rizzo and O'Shea did not even allege "that they had been or would likely be subject to the challenged practices." 95 Victims of police practices need only say that they have been hurt by the police and that there is some police practice to challenge.

The most striking feature of standing analysis in these equal protection cases involving injunctive relief is silence about Lyons standing requirements. The decisions fail to inquire into likelihood of future harm or ask whether the harm will recur. They certainly do not assess credible threat of future harm or follow the factors in the post-Lyons framework. Lyons is clear that " $[\mathrm{p}]$ ast exposure to illegal conduct does not in itself show a present case or controversy regarding injunctive relief ... if unaccompanied by any continuing, present adverse effects." ${ }^{96}$ Silence about this most basic requirement of Lyons evidences a fundamental departure from Lyons standing doctrine in group harm cases-the future harm is presumed in cases involving group-based harm.

Understanding how these equal protection cases relate to Lyons requires looking beyond the case law to the underlying values served by the Lyons analysis. There is nowhere else to look because, although these equal protection cases break every rule of the Lyons doctrine, the Court never cites Lyons. Rather than view these decisions as unprincipled, this Note contends that Lyons and equal protection cases can be understood as sharing a consistent approach. Group-based harm reconciles these

91. Id. at 666 .

92. 455 U.S. 363, 372-74, 377 (1982) (challenging discrimination under the Fair Housing Act, where the Supreme Court determined that Article III standing requirements were applicable and were met).

93. 468 U.S. 737 (1984).

94. See supra notes 88-89 and accompanying text.

95. Allen, 468 U.S. at 755; see O'Shea v. Littleton, 414 U.S. 488, 491-92 (1974) (holding that where plaintiffs challenged racially discriminatory bond setting, sentencing, and jury trial fees, there is an insufficient likelihood that they will again break the law and be subject to these practices); Rizzo v. Goode, 423 U.S. 362, 366-67 (1976) (holding that where plaintiffs challenged police misconduct aimed at minority residents and residents in general, plaintiffs must show a policy or pattern of violations).

96. City of Los Angeles v. Lyons, 461 U.S. 95, 102 (1983) (quoting O'Shea, 414 U.S. at 495-96 (1974)). 
cases. The Lyons Court relied on the prudential standing doctrine limiting standing for injunctive relief to those asserting "generalized grievances" for which no discrete group suffers harm. On the other hand, suspect classifications in equal protection cases create just the sort of group-based harm absent in Lyons. The proposed standing rule operates as follows: If plaintiffs allege group-based harm, such as where plaintiffs allege a racial classification, the court grants standing. Only where plaintiffs allege individual harm does the court reach Lyons questions about whether the plaintiff faces a credible threat.

When racial profiling cases include equal protection claims, groupbased harm is present, obviating the need to follow the Lyons credible threat framework. As in the equal protection cases discussed, victims of police practices need to allege only that they have been harmed by the police and that police maintain a pattern or practice. Such a minimal allegation can be made in almost any racial profiling or police misconduct case.

\section{Voting Rights Cases and Group-Based Harm}

Voting rights decisions illustrate the Supreme Court's approach to standing for injunctive relief in equal protection cases, but with a twist: In voting cases, the only harm that the Court relies upon is group-based. ${ }^{97}$ These "racial gerrymandering" cases have "given the Supreme Court fits" and show just how far the Court will bend to find standing where groupbased harm is alleged.98 The Court struggled with the kind of harm that a group must show when a racial classification is alleged and concluded, in the face of withering dissent, that the group-based racial harm is itself sufficient for standing for injunctive relief, in the absence of any other tangible present or future harm. These cases represent the outer reach of the Court's decisions on standing for injunctive relief, and they suggest the future direction of racial profiling case law.

The Court grants standing based on a group injury created by the racial classification of the district lines, where "a reapportionment plan ... concentrates members of the group in one district and excludes them from others." 99 Standing is granted because racial classifications themselves "threaten to stigmatize individuals by reason of their membership in a racial group and to incite racial hostility." 100 Following this language in Shaw v. Reno, discrimination that "threatens" to stigmatize is sufficient to show harm to a group, and plaintiffs need not allege "actual"

97. See Pamela S. Karlan, All Over the Map: The Supreme Court's Voting Rights Trilogy, 1993 Sup. Ct. Rev. 245, 278 (describing the Court's "complete disregard for standing requirements" in voting rights cases).

98. John Hart Ely, Gerrymanders: The Good, the Bad, and the Ugly, 50 Stan. L. Rev. $607,607,620$ (1998) (" $[T]$ he recent Supreme Court dissents make me feel as if l've entered Mondo Bizarro.").

99. Shaw v. Reno, 509 U.S. 630, 646 (1993) (Shaw $I$ ).

100. Id. at 643 . 
stigmatization or harm to their ability to elect candidates of their choice. Residents of a challenged district need not show concrete injury caused by demonstrated minimization of voting power, nor "minority vote dilution," nor, as in Lyons cases, credible likelihood of future harm to representation. ${ }^{101}$ The Court speculated that "a racial gerrymander may exacerbate . . p patterns of racial bloc voting," but the Court did not require any likelihood of harm as in Lyons. ${ }^{102}$ Richard Pildes and Richard Neimi described the harm as expressive harm, resulting from "ideas or attitudes expressed through a governmental action, rather than from the more tangible or material consequences the action brings about." 103

How is expressive harm in voting cases different from "generalized grievances" for which the Court denies standing? In United States v. Hays, the Court limited standing to those "personally" denied equal treatment, by limiting standing to those who live within the district in question. ${ }^{104}$ Hays and the Shaw decisions share an uneasy relationship, since limiting standing to district members does not explain why stigmatic or expressive harm is only felt by those in a district. Persons anywhere in the state can perceive the message conveyed by race-based district lines. ${ }^{105}$

101. Shaw v. Hunt, 517 U.S. 899, 927 (1996) (Stevens, J., dissenting) (Shaw II) (" $[O]$ ne would think that plaintiffs should be required to put forth evidence that demonstrates that their political representatives are actually unlikely to provide effective representation to those voters whose interests are not aligned with those of the majority race in their district."); United States v. Hays, 515 U.S. 737, 751 (1995) (Stevens, J., concurring) ("Appellees have not alleged or proved that the State's districting has substantially disadvantaged any group of voters in their opportunity to influence the political process."); Shaw I, 509 U.S. at 663 (White, J., dissenting) (standing requires a showing that "the electoral system substantially disadvantages certain voters in their opportunity to influence the political process effectively" (citation omitted)); see also Samuel Issacharoff \& Pamela S. Karlan, Standing and Misunderstanding in Voting Rights Law, 111 Harv. L. Rev. 2276, 2286 n.48 (1998) (describing how the Court has never required an actual showing of vote dilution: "The [Court] ... suggests that such injuries do not form the basis of plaintiffs' standing, because it would be perverse to give standing only to persons who allege injuries they are not required to prove.").

102. Shaw I, 509 U.S. at 648 .

103. Richard H. Pildes \& Richard G. Niemi, Expressive Harms, "Bizarre Districts," and Voting Rights: Evaluating Election-District Appearances After Shaw v. Reno, 92 Mich. L. Rev. 483, 506-07 (1993). The Court adopts the term "expressive harm" in Bush v. Vera, 517 U.S. 952, 984 (1996) ("[W]e also know that the nature of the expressive harms with which we are dealing, and the complexity of the districting process, are such that brightline rules are not available."); see also Richard H. Pildes, Principled Limitations on Racial and Partisan Redistricting, 106 Yale L.J. 2505, 2539 n.I22 (I997) (emphasizing how "the kinds of harms Shaw recognizes are themselves constitutionally less familiar").

104. Hays, 515 U.S. at 745 (1995) ("[W] here a plaintiff does not live in such a district, he or she does not suffer those special harms.").

105. Ely argues that a notion of expressive harm for standing purposes is "untenable: any constitutionally questionable practice sends a constitutionally questionable message, which on this theory would mean that anyone has standing to raise any constitutional issue at any time. And although standing doctrine is malleable even for constitutional law, that's one thing we know it can't mean." John Hart Ely, Standing to Challenge Pro-Minority Gerrymanders, 111 Harv. L. Rev. 576, 581 (1997). 
Perhaps these decisions are unclear because the Court is not preoccupied with wrangling over the precise nature of the harm, but is instead driven by the same concerns as in Lyons; that is, limiting standing for injunctive relief to discrete groups and denying standing to the undifferentiated public. Expressive harm in voting rights cases is sufficient where racial classifications harm groups-even if suspect groups are not themselves harmed. John Hart Ely contends that the "filler people" who are "stuffed" in a majority-minority district suffer a more acute group harm than others in the state because, by being in the district, they suffer reduced influence. ${ }^{106}$ As Ely points out, if standing is based on expressive harm alone, all persons in a state can perceive the racial message that district lines convey and standing is potentially unlimited. The Hays Court may have limited standing to those within the affected district due to this concern.

That group-based harm rationalizes these equal protection cases becomes apparent when the expansive approach to standing in voting cases is contrasted to the restrictive approach to standing in Lujan v. Defenders of Wildlife. ${ }^{107}$ In Lujan, plaintiffs alleged a group harm, but the only interest shared by plaintiffs was a common desire to see endangered species survive. ${ }^{108}$ In voting cases, the Court admits that such expressive harm is sufficient to grant standing. The only difference is that voting cases involve equal protection violations; where members of a suspect group share an equal protection harm, even expressive harm suffices to grant standing.

Racial profiling presents a stronger case for distinguishing Lyons because racial profiling singles out a suspect group for constitutional violations, not just expressive harm. Unlike voting cases, where district lines convey unclear messages and harm those outside the district, racial profiling sends a clear message to a distinct audience. Residents are told that law enforcement is tainted by reliance on racial criteria and threatens their physical safety; while, in voting cases, the message is only that the presence of a bizarrely-drawn majority-minority district dilutes one's vote. Following a group-based approach to standing, plaintiffs in racial profiling cases should only be required to allege that they were harmed pursuant to a policy or practice of racial discrimination.

106. Id. at 587. The Shaw dissenters and several critics counter that it could be just as harmful to be excluded from a district. See Issacharoff \& Karlan, supra note 101, at 2280 (arguing that following Gomillion v. Lightfoot, 364 U.S. 339 (1960) where blacks successfully challenged a redrawing of the boundaries of the City of Tuskegee to exclude all minority neighborhoods, those excluded should have standing to bring a claim, but that blacks excluded are "precisely the group the Supreme Court has held does not have standing to bring a Shaw claim"). One response, though, is that unless a discrete group that is excluded suffers a special harm, as in Gomillion $v$. Lightfoot, persons in the district are usually a more discrete group than all persons in the state who are excluded.

107. See 504 U.S. 555 (1992).

108. See id. at 562-63. 


\section{A Political Process Theory of Standing for Injunctive Relief}

The Court's approach to standing in equal protection cases can be understood as part of a consistent group-based theory of judicial review. Lyons emphasizes that standing is intended to limit injunctive relief to groups rather than to individuals sharing only generalized grievances, citing the line of Supreme Court cases denying standing for prudential reasons. ${ }^{109}$ More recently, the Supreme Court suggested that there is a constitutional dimension to the prohibition on standing for generalized grievances, connected with the prudential requirement that the injury itself not be unduly "abstract." In Federal Election Commission v. Akins, the Court stated that this constitutional element of the prudential limit on standing requires that the injury not be "of an abstract and indefinite nature-for example, harm to the common concern for obedience to law." 10 The Akins Court then describes its approach in these cases: "Whether styled as a constitutional or prudential limit on standing, the Court has sometimes determined that where large numbers of Americans suffer alike, the political process, rather than the judicial process, may provide the more appropriate remedy for a widely shared grievance."111

The Court's approach in Akins echoes John Hart Ely's political process theory that judicial review should be confined to cases involving disfavored minority groups that are consistently denied a voice in the politi-

109. For cases denying standing for prudential reasons, see supra note 77. For criticism of prudential standing doctrine, see Edward A. Hartnett, The Standing of the United States: How Criminal Prosecutions Show that Standing Doctrine is Looking for Answers in All the Wrong Places, 97 Mich. L. Rev. 2239, 2246-48 (1999) (arguing that the Court's requirement of a personalized injury is unfounded and logically leads to absurd results such as denying standing to government prosecutions, because the government does not suffer personal harm when laws are broken); see also Fallon, Of Justiciability, supra note 19, at 26 (criticizing the Lyons Court's use of standing doctrine to "limit judicial involvement in the functions of political institutions of government").

110. 524 U.S. 11, 23 (1998) (internal quotation marks and citations omitted). Lyons also establishes the requirement that "[a]bstract injury is not enough." City of Los Angeles v. Lyons, 461 U.S. 95, 101 (1983). It is unclear what this requirement actually adds to the simple standing requirement that there be a real injury in fact, not a generalized grievance, and then an additional credible threat of future harm. For criticism of the constitutionalization of this part of the prudential standing requirement, see Hartnett, supra note 109, at 2240-41 (arguing that there is no tenable difference between the prudential "no generalized grievance" requirement and the "no abstract injury" requirement; the Court's only example of an abstract injury, a common concern for obeying the law, is also a generalized grievance). But see Cass R. Sunstein, Informational Regulation and Informational Standing: Akins and Beyond, 147 U. Pa. L. Rev. 613, 636 (1999) (analyzing the Court's decision to distinguish between injuries that are "widely shared" and subject to the prudential rule, and injuries that are "abstract" and subject to a constitutional rule, as a "key step").

111. 524 U.S. at 23 (1998); see also Steel Company v. Citizens for a Better Env't, 523 U.S. 83, 97 (1998) (stating that the Court does not grant standing to plaintiffs asserting "'generalized grievances' that the Constitution leaves for resolution through the political process" (internal citations omitted)). 
cal process. ${ }^{112}$ Indeed, in Allen $v$. Wright the Court characterized the Lyons denial of standing for injunctive relief in explicit political process terms, quoting Lyons and stating that "[a]nimating this Court's holdings was the principles that ' $[a]$ federal court . . . is not the proper forum to press' general complaints about the way in which government goes about its business." 113

Ely argues that where the harm is not group-based, persons should seek relief through the political branches, not the courts. Ely advocates a group-based approach to standing in voting rights cases, and argues that equal protection doctrine is grounded in a theory of group-based harm. ${ }^{114} \mathrm{~A}$ theory of group-based harm also explains why the Court loosens standing requirements so dramatically in all equal protection cases. As we have seen, the Court permits wide access to federal courts where groups are harmed by racial classifications. Justice Scalia also emphasizes a political process approach to standing:

[T] he law of standing roughly restricts courts to their traditional undemocratic role of protecting individuals and minorities against impositions of the majority, and excludes them from the even more undemocratic role of prescribing how the other branches should function in order to serve the interests of the majority itself. ${ }^{115}$

Justice Scalia suggests a heightened showing similar to that in Lyons for cases in which there is no group-based harm alleged. "Unless the plaintiff can show some respect in which he is harmed more than the rest of us.... $[\mathrm{H}] \mathrm{e}$ has not established any basis for concern that the majority is suppressing or ignoring the rights of a minority that wants protection ...."116

112. See John Hart Ely, Democracy and Distrust 153 (1980) (arguing that judicial review is appropriate where a majority coalition persistently and irrationally refuses to strike political deals or take account of interests of a minority group).

113. 468 U.S. 737, 760 (1984) (quoting Lyons, 461 U.S. at 111-12).

114. See Ely, Group Harm, supra note 67 , at 220 . Ely added:

In Brown v. Board of Education, the Court's controversial footnote 11 describes the harm caused by segregation as feelings of insecurity felt by black students. The Court did not focus on whether the segregated schools had inadequate resources. Focus on group-based harm obviates the need to rely on controversial showings of psychological harm or other disadvantage, since the racial classification itself is Id. the harm.

115. Antonin Scalia, The Doctrine of Standing as an Essential Element of the Separation of Powers, 17 Suffolk U. L. Rev. 881, 894 (1983).

116. Id. at 894-95. For a sensible criticism of this approach, see Richard $\mathrm{H}$. Fallon et. al., supra note 19, at 145 ("If there is reason to fear that adjudication of sensitive issues of governmental relations would result, isn't the political question doctrine the appropriate rubric under which to deal with that fear?"); see also Steven L. Winter, The Metaphor of Standing and the Problem of Self-Governance, 40 Stan. L. Rev. 1371, 1381 (1987):

The most appealing justification of standing law is that, in preserving the separation of powers, it protects the majoritarian political process from undue intrusion by the unelected judiciary. But not all issues are amenable to the 
Thus, Article 111 standing serves the purpose of screening cases in which there is less of a concern that a minority group has been singled out for disparate treatment. This screening function should be made explicit because standing rules are intended to provide notice at the threshold to guide the expectations of potential litigants. ${ }^{117}$ A political process theory of standing only serves its purpose if it is explicit, so that parties know in advance to channel some reform efforts from litigation to the political process. Silent failure to treat racial profiling cases like other equal protection cases instead implicates judicial legitimacy at critical initial stages of litigation. The doctrine of standing for injunctive relief hangs in disarray, with Lyons case law squarely conflicting with equal protection case law. The groundswell of racial profiling challenges nationwide also urges immediate reconsideration of the current divided standing doctrine. ${ }^{118}$

Two recent decisions demonstrate the harm caused by this confusion in standing doctrine. In Farm Labor Organizing Committee v. Ohio State Highway Patrol, the court recognized that a valid equal protection claim existed, stating: "There can be little dispute that Aguilar and Esparza have standing to sue for damages on an equal protection theory because they allege they were asked about their immigration status on the basis of their Hispanic appearance, and, further, had their green cards seized."119 The court recognized that an equal protection claim has an independent hasis for standing, yet proceeded to apply Lyons to deny standing and dismiss the entire case where each of the defendants had broken a traffic law before being stopped. The court even noted the incongruity in denying standing where any other equal protection case would survive on the same facts-" $[\mathrm{T}]$ hat is the irony of this case and cases like it." 120 Following an equal protection approach, courts should not permit "irony" in inconsistent dismissal of some equal protection cases just because they happen to involve police misconduct or government action. As with all other equal protection cases, an allegation of a practice harming a racial minority should have been sufficient and the action should not have been dismissed.

In a second case, Hodgers-Durgin v. De La Vina, the Ninth Circuit sitting en banc denied standing to pursue injunctive relief based on typical Lyons analysis. ${ }^{121}$ Plaintiffs alleged that the Border Patrol engaged in a

political process. All too often, the inevitable consequence of a decision denying standing is "that the most injurious and widespread Governmental actions c[an] be questioned by nobody. ..."

117. See generally, Little, supra note 21 (arguing that Lyons standing doctrine does not provide clear threshold rules).

118. See supra note 5 and accompanying text.

119. 95 F. Supp. 2d 723, 730 (N.D. Ohio 2000).

120. $1 \mathrm{~d}$.

121. 199 F.3d 1037 (9th Cir. 1999) (denying injunctive relief based on equitable restraint, but emphasizing the insufficient likelihood of future harm where plaintiffs had only been stopped once in ten years). 
pattern of disparately stopping persons of Mexican descent, but named plaintiffs did not allege suffering repeated stops. Several class members had testified that they suffered repeated stops, but Lyons doctrine was murky enough that the lawyers made a mistake and did not select them as named plaintiffs. The court relied on this error to dismiss the case. ${ }^{122}$ The suit can be brought again with new class representatives, satisfying Lyons, but wasting valuable judicial and community resources. Plaintiffs should have been able to avoid dismissal by simply adding an equal protection claim, for which we have seen courts grant standing expansively. The Lyons concerns that the court relied upon were irrelevant where standing could have been granted solely based on presence of an equal protection claim alleging group-based harm. ${ }^{123}$

Standing doctrine will only function effectively if courts resolve this inconsistency between treatment of standing for injunctive relief in Lyons and equal protection cases. Courts should explicitly distinguish Lyons when considering standing in equal protection cases involving groupbased harm. Prior to Atkins, grounding the doctrine of standing for injunctive relief on prudential, non-constitutional concerns might have seemed ill-advised. Now that Atkins has defined a constitutional side to the prudential doctrine, this proposed political process theory of standing rests on firm constitutional ground. ${ }^{124}$

A full articulation of a political process theory of standing is beyond the scope of this Note, but the theory finally clarifies the proper place of Lyons in standing doctrine. Where a member of the undifferentiated public is harmed, the Court under Lyons requires the plaintiff to show a credible threat of future harm before she can pursue injunctive relief. However, in racial profiling cases, minorities are distinguished from the public and targeted as a group. In these cases, Lyons concerns are irrelevant. ${ }^{125}$ Ely even suggests in passing that in racial profiling challenges the

122. See id. at 1048 (Reinhardt, J., concurring):

One of those class members, Mr. Luis Villa, was stopped on more occasions than he could recall. Had Mr. Villa been a named plaintiff, his showing of likely future injury would in all probability have been sufficient to overcome summary judgment. That fact alone shows that this is a case about the selection of improper class representatives....

123. Plaintiffs did not allege a Fourteenth Amendment claim, but only a Fourth Amendment claim. The court could have suggested adding an equal protection claim. The concurrence did emphasize that standing would be possible in future cases with equal protection claims in which named plaintiffs suffered repeated stops. See id. at 1048 (Reinhardt, J., concurring) ("[T]he federal courts have the primary obligation to protect constitutional rights, and . . a appropriate class representatives may seek relief on behalf of minority group members whose Fourteenth Amendment rights are threatened.").

124. Ely might argue that political process concerns gird all judicial review, so that a synthesis of Lyons and equal protection standing law makes perfect constitutional sense regardless of Atkins.

125. Political process concerns are especially great because racial profiling often affects minors who cannot vote or people in transit to whom local police are not directly accountable. Advocates of community policing suggest that only new kinds of political 
group-based harm is presumed, even given allegations far less strong than those that Lyons requires:

If a traffic cop tells someone he's stopped for doing 60 in a 55$\mathrm{mph}$ zone that the reason he singled him out-he generally looks the other way unless someone's doing 68 -is that he (the driver) is black, the driver has a solid race discrimination claim, even if he can't prove that a single other black driver has been thus treated, let alone all or even most of them. ${ }^{126}$

\section{CONCLUSION}

Lyons requirements are well suited to evaluating facts in situations involving individual encounters and claims of official policy or practice. However, in equal protection cases where group-based harm is alleged, the racial classification is itself a sufficient harm, creating a presumption of standing in racial profiling cases. Standing requirements for injunctive relief serve the purpose of ensuring that minority groups have access to federal courts. Thus, plaintiffs in racial profiling cases should be required to look no farther than the Fourteenth Amendment.

institutions can make police departments accountable for practices like racial profiling. See Debra Livingston, Police Discretion and the Quality of Life in Public Places: Courts, Communities, and the New Policing, 97 Colum. L. Rev. 551, 655 (1997) ("In large urban departments where police attend to the concerns of many distinct communities, . . . [some] mechanisms of political accountability may be too far removed from the concerns of local neighborhoods to insure responsiveness to these concerns.").

126. Ely, Group Harm, supra note 67, at 220. 